Board of Governors of the Federal Reserve System

International Finance Discussion Papers

Number 699

March 2001

PRICE LEVEL CONVERGENCE, RELATIVE PRICES, AND INFLATION IN EUROPE

John H. Rogers

NOTE: International Finance Discussion Papers are preliminary materials circulated to stimulate discussion and critical comment. References in publications to International Finance Discussion Papers (other than an acknowledgment that the writer has had access to unpublished material) should be cleared with the author or authors. Recent IFDPs are available on the Web at www.federalreserve.gov/pubs/ifdp/. 


\title{
PRICE LEVEL CONVERGENCE, RELATIVE PRICES, AND INFLATION IN EUROPE
}

\author{
John H. Rogers*
}

\begin{abstract}
If price levels are initially different across the euro area, convergence to a common level of prices would imply that inflation will be higher in countries where prices are initially low. Price level convergence thus provides a potential explanation for recent cross-country differences in European inflation, a worrisome development under the ECBs "one-size-fits-all" monetary policy. I present direct evidence on price level convergence in Europe, using a unique data set, and then investigate how much of the recent divergence of national inflation rates can be explained by price level convergence. I show that between 1990 and 1999 prices did become less dispersed in the euro area. Convergence is especially evident for traded goods, and more in the first half of the 1990s than the second half. By some measures, traded goods price dispersion across the euro area is now close to that across U.S. cities. Despite an ongoing process of convergence, deviations from the law of one price are large. Finally, I find a statistically-significant and robust negative relationship between the 1999 price level and 2000 inflation rate in Europe, and that the contribution of price level convergence to explaining inflation differentials is often quite important economically. Still, factors other than price convergence explain most of the crosscountry inflation differences.
\end{abstract}

JEL classification: E31, F36, F41

Keywords: prices, economic integration, exchange rates, purchasing power parity, euro

* Senior economist, International Finance Division, Board of Governors of the Federal Reserve System, Washington, D.C. 20551. 202-452-2873, John.h.Rogers@ frb.gov. I would like to thank Jon Faust, Joe Gagnon, Mike Gilbert, Chris Gust, Dale Henderson, Gary Hufbauer, Jane Ihrig, Karen Johnson, Steve Kamin, David Kobuszewski, Hayden Smith, Vince Reinhart, Yuhki Tajima, Erika Wada, and seminar participants at Bocconi University. Part of this work was completed while the author was a visitor in the economics department at Georgetown University. The views in this paper are solely the responsibility of the author and should not be interpreted as reflecting the views of the Board of Governors of the Federal Reserve System or of any other person associated with the Federal Reserve System. 


\section{Introduction}

Consumer price inflation in the euro area declined steadily for most of the 1990s.

However, in the last two years, both headline and core inflation have risen throughout the area, and sizable cross-country differences in inflation have re-emerged. This is illustrated by Figure 1 , which displays the headline consumer price inflation rate for the euro area as a whole and for selected member countries. In the final quarter of 2000, all euro area countries had headline inflation rates above the European Central Bank's (ECB) two percent medium-term ceiling, with rates ranging from a touch above 2 percent in France to nearly 6 percent in Ireland; in Greece, which joined the euro area January 1, 2001, inflation was 3.8 percent.

Cross-country inflation differentials are an important source of concern under the ECBs "one-size-fits-all" monetary policy. First, their existence suggests that the common monetary policy is likely to be too stimulative for some countries and too restrictive for others.

Differences in national inflation rates imply differences in real interest rates and real exchange rates across euro area countries. This in turn can produce a destabilizing effect, as the countries with relatively low (ex-post) real interest rates are the higher-inflation countries; presumably, relatively less stimulus is warranted in these countries.

One factor that may be contributing to cross-country differences in inflation is price level convergence or "inflation catch-up". This has been discussed prominently in policy-making circles. ${ }^{1}$ According to the argument, if prices expressed in a common currency are initially different across countries, convergence to a common level of prices implies higher inflation in countries where prices are initially low. The idea is depicted very simply in Figure 2, with

${ }^{1}$ See ECB President Wim Duisenberg's September 6, 2000 speech “Are Different Price Developments in the Euro Area a Cause for Concern?" ( http://www.ecb.int/ ), or "Inflation Differentials in a Monetary Union," in the Monthly Bulletin of the European Central Bank, October 1999, pp. 36-44. 
hypothetical dynamic paths of the price level for two countries: a relatively low-price country, call it "Portugal", and a high-price country, "France". Consider the average price level for the area to be normalized at 1.0. Abstracting from the drift in prices each year, this is thus the area average price level in every year and also the long-run equilibrium (hypothetically to be reached in 2030). Clearly, if there is convergence of prices in the long run, then low-price Portugal must experience higher inflation than France, at least for some time along the transition path. ${ }^{2}$

There are several reasons to expect at least some price convergence in Europe. First, there might be convergence of traded goods prices. Progress toward a single market, including already-completed trade liberalization and adoption of the single currency, should narrow differences in common-currency prices across countries, at least for traded goods.

Second, increased economic integration in Europe may induce convergence of non-traded goods prices. The Balassa (1964)-Samuelson (1964) hypothesis provides an explanation why. Suppose that the initially low-price countries are also relatively poor countries. ${ }^{3}$ If there is convergence of productivity levels, the initially poor / low-price countries will experience faster productivity growth compared to the wealthier, high-price countries. Assume that this convergence takes place in the traded goods sector, while productivity in the non-traded goods sector is either unchanged or is converging at a much slower rate. A rise in productivity in the traded goods sector raises output and wages in that sector, which in turn pushes up wages and

${ }^{2}$ Although the example is meant to be illustrative only, the numbers in Figure 2 correspond to the actual "overall" price levels that I calculate for these countries in the years displayed.

${ }^{3}$ Figure 3 below verifies that this relationship is present in the European data used in this paper. 
hence prices in the non-traded goods sector. ${ }^{4}$ Because convergence of productivity and living standards implies that the productivity gains are greater in the low-price countries, non-traded goods prices will be rising faster there than in countries where prices are already high.

Thus, countries with initially low prices might experience relatively high inflation following closer economic integration. This could occur through inflation of traded goods prices, non-traded goods prices, or both.

In addition to knowing whether or not prices are converging in Europe, and whether price level convergence accounts for much of the observed inflation differentials in Europe, it is also useful to know whether convergence is operating mostly through the prices of tradeables or nontradeables. If price level convergence works mostly through tradeables (and convergence is important as an explanation for inflation divergence), then part of the current divergence of inflation in the euro area may be transitory, part of a potentially-brisk transition toward a common price level in the region. However, to the extent that price level convergence occurs through the relatively gradual process of convergence of productivity and living standards, the resulting cross-country inflation differentials may be long-lived.

Two important policy implications follow from this discussion. First, the price level convergence hypothesis suggests that as the euro area widens to include Greece and, potentially, other relatively low-price countries in Eastern Europe, inflation in the new member nations could rise substantially. Second, it seems appropriate to regard the part of a country's inflation rate that is attributable to price level convergence as an inevitable by-product of increased integration.

${ }^{4}$ This is due to the assumption that labor is mobile between sectors. The absence of a price increase in the traded goods sector follows from the assumption that the law of one price holds for the traded good. For a textbook treatment of the classic model, see Obstfeld and Rogoff, (1996, ch. 4). 
Assuming we can measure this component of inflation accurately, it arguably makes sense to categorize it differently -- in much the same way that central banks tend to distinguish core inflation from headline inflation in their thinking.

Despite the prominent attention that has been given to price level convergence in policymaking circles, and despite obvious links to the large academic literature on purchasing power parity, there is little empirical evidence indicating whether or not prices in Europe actually are converging. Nor, to my knowledge, has there been any quantitative work examining the importance of price level convergence as an explanation for cross-country differences in inflation. Canzoneri, Cumby, Diba, and Eudey (2000) examine the factors that give rise to longrun inflation differentials in Europe, but do not directly examine price level convergence. The closest in spirit to my paper is perhaps Cecchetti, Mark, and Sonora (2000), who estimate halflives of deviations from PPP across U.S. cities using the aggregate consumer price index. They discuss the implications of their U.S. estimates for price level convergence in Europe. Parsley and Wei (1996) also examine the dynamic convergence of prices across U.S. cities by estimating half-lives of deviations from the law of one price.

Much of the reason for the relative lack of work in these areas is due to data limitations. Canzoneri, Cumby, Diba, and Eudey (2000) and Cecchetti, Mark, and Sonora (2000) use price index data, and so cannot make direct comparisons of price levels at any point in time. Crucini, Telmer, and Zachariadis (2000) do examine actual prices for a large sample of items in European cities, but only for $1985 .^{5}$

${ }^{5}$ These authors thus focus on explaining the cross-section of deviations from the law of one price in that year, attempting to distinguish between country (or "border") effects as in Engel and Rogers (1996) and "brand" effects, rather than on price convergence over time. 
In this paper I present direct evidence on the price level convergence hypothesis, using a unique data set of prices across European cities. ${ }^{6}$ I first show that, between 1990 and 1999, prices became less dispersed in the euro area. Convergence was especially evident for traded goods, and was stronger in the first half of the 1990s than the second half. For traded goods, measures of price dispersion have fallen more in the euro area than across U.S. cities, and by some estimates euro area prices have converged close to the U.S. level. I also show that there is evidence of convergence toward the law of one price in the euro area, but that deviations from this equilibrium remain large for many items, even tradeables. Finally, I show that price level convergence is a robust, statistically-significant factor explaining current cross-country differences in euro area inflation. However, the degree to which this factor is economically important varies from country to country, and typically other factors such as output gaps and GDP growth rates provide at least as important an explanation of inflation performance.

\section{The Data}

There is no ready source of data on aggregate price levels that suits the purpose of this study. Therefore, as described in the Appendix, I constructed the indexes of European price levels from actual prices of 168 goods and services in 26 cities in 18 countries. ${ }^{7}$ The 18 countries comprise all 11 original members of the euro area, six other European nations, and Israel. The

${ }^{6}$ Hufbauer, Wada and Warren (2000) first exploited this data set by estimating prospective welfare benefits that would accompany a hypothetical convergence of prices worldwide. Rogers (2000) and Rogers, Hufbauer, and Wada (2001) also make use of the data set.

${ }^{7}$ The cities are Amsterdam, Athens, Barcelona, Madrid, Berlin, Dusseldorf, Frankfurt, Hamburg, Munich, Brussels, Copenhagen, Dublin, Geneva, Zurich, Helsinki, London, Lisbon, Luxembourg, Lyon, Paris, Milan, Rome, Oslo, Stockholm, Tel Aviv and Vienna. 
raw price data are collected annually in the spring by the Economist Intelligence Unit (EIU), which since 1981 has calculated cost-of-living indexes for multinational corporations that move employees around the world. The EIU survey teams are instructed to record local prices of tightly specified goods such as 1 kilogram of white bread, 1 litre of Coca-Cola, a tube of toothpaste, a pair of blue jeans, and services such as "woman's haircut and blow dry (tips included)" and rent on unfurnished apartments of 5 to 6 rooms. ${ }^{8}$ The entire sample of goods and services is listed in Appendix Table A-1. Although all goods have both tradeable and nontradeable components, I designate the service-type items as "non-tradeable" and consider the rest to be "tradeable". The local-currency prices reported by the EIU are converted to U.S. dollars at the market exchange rate prevailing at the time of the survey. In this paper I analyze data from 1990, 1995, and 1999.

To construct a price index from the raw data, I assign each of the items to one of the 12 two-digit categories comprising the European harmonized consumer price index (listed in Table A-1), and weight prices equally within these categories. Because consumption patterns differ across countries, I use different sets of country-specific weights. The weights are listed in Appendix Table A-2. I normalize the resulting indexes to make the mean for all cities taken together equal to 1.0 each year. Thus, a price level of 0.91 for Dublin in 1995 implies that prices were 9 per cent lower there than in the average city in that year. For countries with more than one city in the sample, the national price index is constructed using a population weightedaverage of the individual city indexes.

Separately, I analyze prices of the same goods in the 14 U.S. cities that are also included

${ }^{8}$ Some additional information about the data is provided in Economist Intelligence Unit (1998). 
in the EIU survey. ${ }^{9}$ Because the United States has long been a functioning monetary union, the results serve as a useful basis of comparison with Europe.

\section{Missing observations and outliers}

The EIU data set does not contain a price quote for every city and every good in every year. This is potentially critical, as it would be misleading to measure price level convergence using a sample of items whose composition changes substantially from one year to the next. In addition, any comparison of price dispersion within the euro area and the U.S. could be contaminated if the sample of items differs radically between the two regions.

Because of this, I use three different criteria for deciding whether or not to include an item in the sample. The first is a "100 percent cut-off rule", in which an item is included only if a price quote is recorded in every year for all 40 cities (26 European, 14 U.S.). This cut-off rule leaves us with a sample of 100 items, 86 of which are classified as "tradeables". The other two criteria are "90 percent" and "75 percent" cut-off rules. In these cases, an item is included in the sample as long as there are price quotes in every year for at least 36 cities and 30 cities, respectively. These cut-off rules produce sample sizes of 141 items (110 of which are tradeables) and 153 items (112 tradeables), respectively. I conduct the analysis on all three samples. The results are largely robust, so I mainly depict the results using the 100 and 75 percent rules. $^{10}$

Finally, for the handful of obvious typos in the data, I deleted the observation. An

${ }^{9}$ Atlanta, Boston, Chicago, Cleveland, Detroit, Honolulu, Houston, Los Angeles, Miami, New York, Pittsburgh, San Francisco, Seattle and Washington DC.

${ }^{10}$ The correlation between the "overall" price index calculated under the $100 \%$ cut-off rule and the $75 \%$ cut-off rule, for example, in $(1990,1995,1999)$ is $(0.94,0.91,0.84)$ for the euro area cities and $(0.97,0.93,0.96)$ for the U.S. cities. 
example is for Milan, where the price of a "paperback novel" in 1990 is recorded as $\$ 0.80$. In

1995 and 1999, the price appears in the data set as $\$ 9.94$ and $\$ 8.97$, respectively. The 1990 price in Rome is recorded as $\$ 8.77$. Thus, the Milan price in 1990 is deemed to be a typo. ${ }^{11}$

\section{A first glimpse of the price indexes}

The constructed price indexes have several interesting characteristics. First, consistent with the Balassa-Samuelson proposition, low-price countries tend to be relatively poor countries. Figure 3 depicts the relationship between the overall price index and per capita GDP, for $1999 .{ }^{12}$ In countries like Portugal, Spain, and Greece, prices are around 15 to $20 \%$ lower than average, while per capita incomes are well below European averages. This relationship is also found in data from other sources (Kravis and Lipsey (1983), Summers and Heston (1991)).

Second, as displayed in Figure 4, there is a very strong, positive correlation between the change in the relative price of non-traded goods to traded goods and the growth rate of labor productivity in manufacturing. ${ }^{13}$ For example, in the latter half of the 1990s, Ireland experienced remarkable growth in productivity, averaging 4 percent annually, and a comparatively steep rise in the price of non-tradeables relative to tradeables. The relationship depicted in Figure 4 is also

\footnotetext{
${ }^{11}$ I was fairly conservative in defining typos, as it is important not to confuse them with a large deviation from the law of one price. An extreme example of the latter comes from the category "visit of four to a nightclub (1 drink included per person)". For 1999, the price is $\$ 628.10$ in Paris and $\$ 64.00$ in Luxembourg, implying a very large deviation from the law of one price. The deviation is of similar size in the other years. This example gives rise to the obvious question of comparability across locations in the item being sampled. On the other hand, one might conclude (if only from introspection) that perhaps the price differential accurately reflects the relative nightlife opportunities in the two cities.

${ }^{12}$ The price index is the one calculated using the $75 \%$ cut-off rule. The income measure is the country's per capita GDP relative to the U.S., converted into dollars at "PPP exchange rates". As described in the data appendix, this is obtained from the IMFs World Economic Outlook database.

${ }^{13}$ This measure is appropriately taken to be a proxy for productivity in the traded goods sector. See Gust and Marquez (2000) for a detailed discussion of the estimates of productivity growth.
} 
consistent with existing evidence from other data sources (see DeGregorio, Giovannini, and Wolf (1994)), and is precisely the relationship predicted by the textbook two-sector model sketched in the introduction (Obstfeld and Rogoff (1996), ch. 4).

For the U.S. sample, New York is always the most expensive city, with an overall price level near or above 1.40 in each year. Prices in San Francisco rose relative to other cities during the decade, presumably as a by-product of the boom in Silicon Valley. San Francisco is the second most expensive city in the U.S. sample -- over-taking Chicago and Los Angeles between 1990 and 1995 -- with prices nearly $29 \%$ above the U.S. average in 1999. Pittsburgh is the lowest-price city in the sample; its 1999 overall price level is 0.82 . For housing items such as apartment rents, prices in New York and San Francisco are as much as 9 times higher than in Pittsburgh; their non-tradeables index overall is about $2 \frac{1}{2} 2$ times higher than Pittsburgh's.

\section{Price Level Convergence}

Table 1 presents direct evidence on price convergence within the euro area and the United States. The upper panel reports the standard deviation of prices across locations, a measure of price dispersion, in three years - 1990, 1995 and 1999 - and for three different price indexes overall (all items), traded items, and non-traded items. For robustness, a second measure of dispersion -- the spread between the highest and lowest price city -- is reported in the lower panel. The results in Table 1A are for the sample using the $75 \%$ cut-off rule for including series, while results for the more limited sample defined by the $100 \%$ rule are contained in Table 1B.

As seen in the first row of Table 1A, there is a slight decline in overall price dispersion over the full period within the euro area, with the standard deviation falling from 0.12 in 1990 to 0.11 in 1999. There is much stronger evidence of convergence for traded goods, especially in the 
first half of the 1990s -- a period that includes the major liberalization of trade in goods and movement of factors of production. As seen in row 2 of either the top or bottom panel, our measures of traded goods price dispersion fall by at least one-half over the 1990s. As expected, there is much more dispersion of non-tradeables prices than tradeables prices, and no evidence of convergence for non-tradeables over the decade..$^{14}$

According to the lower half of each panel in Table 1A, there is little evidence of an ongoing process of price convergence across cities in the United States. Even for tradeables, our measures of dispersion barely budged over the decade, with the standard deviation falling from 0.05 in 1990 to 0.04 in 1999 and the spread falling from 0.18 to 0.14 .

Table 1A also indicates that traded goods prices have been more equal across cities in the United States than the euro area, especially early in the decade. This probably reflects the longstanding absence in the United States of policy restrictions on trade in goods or factor mobility. However, the decline in traded goods price dispersion in the euro area has brought the level of dispersion considerably closer to that in the United States: 0.06 versus 0.04 for the standard deviation and 0.25 versus 0.14 for the spread, as of 1999. In contrast, the prices of non-traded items have been less equal across the United States than the euro area, mostly due to the much greater dispersion of housing prices across U.S. cities. ${ }^{15}$ In both regions, non-tradeables prices show little tendency to converge over time.

Table 1B confirms that the convergence results just discussed are robust to choosing a

\footnotetext{
${ }^{14}$ The results are very similar when we consider the full sample of 26 European cities (i.e., adding Athens, Copenhagen, Geneva, Zurich, London, Oslo, Stockholm, and Tel Aviv). There is slightly more dispersion of prices across all 26 cities than the 18 euro area cities, and in the larger sample relatively more convergence took place between 1995 and 1999 than between 1990 and 1995.

${ }^{15}$ The weight on housing in the overall U.S. price index is 30 percent, amounting to about onehalf of the non-tradeables index. The weight on housing in any country of the euro area is no larger than Germany's 20.8 percent. See Table A-2 for the full set of weights.
} 
sample of items based on the 100 percent cut-off rule. According to Table 1B, there is evidence of price convergence in the euro area but not the United States; convergence is especially strong for traded goods, and more evident in the first half of the 1990s than the second; the level of traded goods price dispersion in the euro area is approaching that of the Unites States; and nontradeables prices are more disperse in the United States than the euro area.

\section{The law of one price}

The results above indicate that, for a weighted-average of prices of individual items, there has been a process of convergence in the euro area, at least for tradeables. However, those results potentially mask important differences in the degree of convergence across items. An item-by-item analysis of deviations from the law of one price could provide perspective on the magnitude of the remaining dispersion of those price indexes.

Figure 5 depicts absolute deviations from the law of one price for each of the 153 items in the sample determined by the $75 \%$ cut-off rule. The upper panel compares deviations in 1990 and 1999 for euro area cities, while the lower panel compares deviations in the euro area and the U.S. in 1999. The absolute deviation from the law of one price is calculated as $\operatorname{Abs}\left[\left(1-\mathrm{P}_{\mathrm{j}} / \mathrm{P}_{\mathrm{k}}\right)_{\mathrm{m}}\right]$, for all city pairs $(j, k)$ in the particular region and for each item $\mathrm{m}$. This produces an array of deviations containing 153 elements for the euro area city pairs and 91 elements for the U.S. city pairs, for every item in the sample. ${ }^{16}$ I use these arrays to compute the median absolute deviation from the law of one price for each good.

According to the upper panel of Figure 5, deviations from the law of one price in the euro area are smaller in 1999 than 1990. Although the amount of the drop in the deviation differs across goods, the reduction is across the board, with only a few items exhibiting larger deviations

\footnotetext{
${ }^{16} \mathrm{~A}$ sample of 18 euro area cities produces $(18 \times 17) / 2=153$ relative prices and hence deviations from the law of one price. It is purely coincidental (not to mention a point of potential confusion!) that there are also 153 items in the sample determined by the $75 \%$ cut-off rule.
} 
in 1999 than 1990. In the full sample of over 20,000 deviations from the law of one price, the number exceeding 0.50 in absolute value fell from 34 percent in 1990 to 26.5 percent in 1999. Figure 5 also indicates that deviations are smaller for tradeables than non-tradeables on average.

Although deviations from the law of one price in the euro area fell between 1990 and 1999, they remain large for many items. Even for traded goods, the median deviation is frequently above 0.20 . In 1999, deviations from the law of one price less than 0.10 occur in only 2.4 percent of the 20,751 total cases.

As seen in the bottom panel of Figure 5, deviations from the law of one price in 1999 are generally smaller in the United States than the euro area. This is true for 90 of the 153 items, but mostly for traded goods. Deviations from the law of one price in non-tradeables, displayed on the right side of the panels, are on the whole larger in the U.S. than the euro area.

Thus the analysis of deviations from the law of one price for the individual items generally echoes the convergence results for the weighted-average of prices above. The only major difference is that for non-tradeables there is more evidence of convergence toward the law of one price in the individual items than there is for the weighted-average price index.

\section{Inflation in Europe}

The evidence on price convergence in the euro area implies a negative relationship between initial price levels and subsequent inflation during the 1990s. Additional evidence indicates that this relationship is also present in more recent data. The scatter plot of 18 countries in Figure 6 relates 1999 price levels (calculated using the $75 \%$ cut-off rule) to the 4 -quarter 2000Q4 rate of inflation in those countries. The pattern shows that recent inflation has indeed 
been higher in countries that had relatively low prices in $1999 .{ }^{17}$ This result is very robust to alternative measures of inflation such as (i) consumer price inflation excluding energy and (ii) inflation of the GDP deflator. It also holds in an analysis of 1995 price levels and inflation rates in subsequent years. ${ }^{18}$ However, it does not hold for the 14 U.S. cities, where the correlation between 1999 price level and year 2000 inflation rate is 0.16 .

Table 2 presents cross-country regressions for Europe to determine whether the negative correlation between current inflation and 1999 price levels remains important once additional variables that also influence inflation are taken into account. The dependent variable in these regressions is the country's 4-quarter rate of consumer price inflation in 2000Q4. Explanatory variables include the 1999 values of the price level, real GDP growth rate, output gap, and per capita real GDP relative to the United States (see the appendix for the data sources). Several of these variables were discussed, and depicted graphically, in section 2. The growth rate of real GDP is included in the regression to capture possible "speed-limit effects" on inflation, which may be important independent of the customary effects of the output gap, even though the two explanatory variables are highly correlated. Relative per capita GDP in 1999 is included to account for the tendency of low-price countries to be relatively poor countries, as seen in Figure 3. I also consider openness to non-EU trade in 1999, measured as total merchandise trade (exports plus imports) with the rest of the world less total trade with other members of the

\footnotetext{
${ }^{17}$ The unconditional correlation between 1999 price level and 2000Q4 inflation for the 11 original euro area countries is -0.64 . The correlation with 1999 price level is negative for inflation rates throughout the year 2000 (e.g., it is -0.70 with the December 2000 rate). The 2000Q4 figure seems preferable to either a monthly rate, which is more affected by temporary blips, or the yearly rate for 2000 (given lags associated with convergence).

${ }^{18}$ For example the correlation between the 1995 price level and the average annual inflation rate for 1996-99 is - 0.50 for the 11 euro area countries. The negative correlation between 1995 price level and subsequent inflation rate appears to persist for several years -- it is -0.42 for the 1999 inflation rate and -0.27 for 2000 .
} 
European Union, as a share of GDP. This variable is designed to capture relative exposure to inflation imported from abroad, either directly or through the effects of the weak euro.

As indicated in Table 2, the correlation between current inflation and the1999 price level is negative and significant. Business cycle effects, initial income levels, and openness to non-EU trade are also important determinants of inflation. Column 1 reports the findings for the original euro area countries alone. The coefficient on the 1999 price level is -4.53 , with a standard error of 0.30. Column 2 indicates that the negative correlation between current inflation and 1999 price level is also large for the full sample of 17 European countries. The business cycle and openness effects in this regression are quite similar to those in the first regression.

Column 3 reports results for an analysis of inflation excluding energy prices, for the 11 original euro area countries. The coefficient on the 1999 price level remains negative and significant. The notable differences, relative to the findings in Column 1, are the increased importance of 1999 GDP growth and per capita GDP, and the decreased importance of openness. This is just as expected: "domestic" factors like GDP growth have a relatively large effect on core inflation rates, while the "external" factors proxied by our openness measure (the weak euro, oil or other import price changes) have a relatively large effect on energy prices and hence headline inflation.

The regressions provide evidence on the economic importance of the 1999 price level in explaining current inflation divergence. The coefficient of -4.53 in column 1 implies that a country whose 1999 price level was 10 percent lower than the average would have an inflation rate in 2000Q4 about one-half percentage point higher than a country with the average 1999 price level. The magnitude is similar for the other two specifications. As indicated at the bottom of the table, the 1999 price level explains between 12 and 31 percent of the cross-country variation in inflation. 
To gauge the importance of the 1999 price level relative to the other explanatory variables, consider Ireland, whose inflation performance -- nearly 3 percentage points over the simple country-average in 2000Q4 -- has grabbed headlines as a source of concern for the ECB (see Duisenberg's speech cited above). Noting that Ireland's price level was about 7 percent below average in 1999, the regression estimate in column 1 implies that price level convergence accounts for only about one-third percentage point of the deviation of current Irish inflation from the European average. The estimates in column 1 also imply that Ireland's rapid GDP growth rate in 1999 -- 6 percentage points above the euro area average of 3.8 percent -- pushed Irish inflation nearly $1 \frac{1}{2}$ percentage points above average in 2000Q4. Finally, Ireland is the most open of the euro area countries to non-EU trade, and hence might be experiencing higher than average imported inflation, perhaps due to weakness in the euro. The estimate in column 1 implies that this contributed 0.4 percentage points to Ireland's above average inflation rate. ${ }^{19}$

Thus, a rough decomposition of Ireland's divergent inflation performance indicates that just under one percentage point is due to "international factors" -- price level convergence and openness -- that are beyond the influence of the customary tools of Irish policy. However, nearly 2 percentage points are due to conventional "national" factors (GDP growth and the output gap) that are more directly affected by domestic policy. ${ }^{20}$

To see the importance of price level convergence in explaining inflation divergence for each European country, consider Table 3, which displays the deviation of each country's 2000Q4 inflation rate from the area average and the amount of the deviation that is accounted for by the

\footnotetext{
${ }^{19}$ Romer (1993) finds a negative cross-sectional relationship between openness and inflation in a very broad sample of countries, while postulating a mechanism for this link that is much different from the one I have in mind. (Hence he uses a measure of overall trade openness, in contrast to my use of openness to non-EU trade). Among Romer's group of 18 highly developed countries, the opennessinflation relationship is insignificant (p. 883).
}

${ }^{20}$ The regression residual, also a factor in the decomposition, is a negligible -0.02 for Ireland. 
1999 price level. The latter is derived from the estimates in column 2 of Table 2. In many cases, the price level convergence effect is quite important. For example, in the relatively poor and low-price countries of Greece, Portugal and Spain, the 1999 price level accounts for a full percentage point of the above-average inflation performance, while GDP gap and growth rate effects have a relatively small influence.

\section{Robustness}

The European Central Bank does not weight the inflation rates of each member nation equally, either in their thinking or in the formal construction of the area-wide inflation aggregate. Although there is a rationale for the equal-weighted scheme in the regressions above ${ }^{21}$ it is useful to check robustness to alternative specifications. In the first column of Table 4, I present a weighted least squares (WLS) estimate of the first specification of Table 2, in which the residuals are weighted by the country's population in 1999. The WLS point estimates are all remarkably close to the OLS estimates of Table 2, but in several cases have much larger standard errors. The coefficient on the 1999 price level is -4.23 , which is still significant at 5 percent given the standard error of 1.54 , compared to the OLS estimate of $-4.53(0.70)$.

Specification 2 of Table 4 shows that the results are robust to using the 1999 price level computed using the $100 \%$ cut-off rule instead of the $75 \%$ rule. I also looked at several specifications that add measures of productivity growth rates (labor and total factor) and consumption tax rates to the basic regression. These variables were often insignificant or of the wrong sign (e.g., the growth rate of labor or total factor productivity sometimes came in negative) and, with the exception of rendering the openness coefficient insignificant, generally had no effect on the results. A representative specification is given in column 3 of Table 4, which includes the 1999 growth rate of labor productivity in manufacturing. The coefficient on

\footnotetext{
${ }^{21}$ Defection from the union of even the smallest member could be the proverbial hole in the dike.
} 
the 1999 price level is now $-7.50(0.54)$, while the business cycle effects are fairly similar to earlier estimates. Labor productivity growth enters positively, but with a t-statistic below unity.

\section{Are Balassa-Samuelson effects at work?}

It would be useful for policymakers to know if price level convergence, and its effects on inflation, is working mostly through traded goods prices or through the relatively gradual process of convergence of productivity, living standards, and the price of non-tradeables. The evidence presented so far sheds mixed light on the issue. The relative price of non-tradeables has risen faster in countries with higher productivity growth rates (recall Figure 4), just as the textbook Balassa-Samuelson model predicts. Several of the high inflation countries in 2000, such as Ireland, Portugal, and to some extent Greece, are also high-productivity growth countries (as of 1999). However, there are noteworthy exceptions to the high productivity--high inflation nexus, such as Austria and Spain, and the correlation between productivity growth and HICP inflation for 1996-1999 is -0.001. Also, measures of productivity growth do not generally enter the regression for 2000Q4 inflation positively and significantly, as indicated by Table 4. Measures of price dispersion displayed in Table 1 indicate that from 1990 to 1999 convergence has occurred almost exclusively through traded goods prices, but according to Figure 5 the drop in absolute deviation from the law of one price was almost as large for non-tradeables as for tradeables.

The final specification of 2000Q4 inflation in Table 4 provides some additional perspective. In this regression I replace the 1999 overall price level with the non-tradeables and tradeables indexes separately. Both indexes enter negatively and significantly. The coefficient on the traded goods price index is larger in absolute value than that on the non-tradeables price index, -2.03 versus -1.40 , but with a much larger standard error as well (0.31 versus 0.09$)$. Thus, countries with low prices in 1999 for either traded goods or non-traded goods experienced higher 
overall inflation in 2000. This suggests that price level convergence may now be occurring through both tradeables and non-tradeables, even if the latter effect is not necessarily working through measured productivity. ${ }^{22}$

\section{Implications for expansion of the euro area?}

The concern that increased economic integration in the euro area might result in higher inflation in poor and low price countries is likely to be an even greater policy concern in the future, as expansion brings full membership to Greece and, potentially, to other relatively lowprice countries such as the Czech Republic, Estonia, Hungary, Poland, and Slovenia. In Table 5 I display the price levels for Budapest, Warsaw, and Prague, calculated in the manner above using data from the same EIU sample (and HICP weights for Greece). The price levels are all well below the European average -- more than 25 percent below prices in Lisbon, the least expensive of the original 11 euro area members -- despite the fact that prices in these East European cities rose considerably during the 1990s. The regressions of Table 2 suggest that accession into monetary union could quickly boost inflation in these countries by at least a couple of percentage points above the area average.

\section{Conclusion}

Price level convergence has been put forth by prominent policymakers as a potential explanation for inflation divergence in the euro area. This paper provides evidence that there is an on-going process of price level convergence in the euro area, especially for traded goods. By some measures, traded goods price dispersion across the euro area is now close to that of U.S. cities. In addition, it is shown that deviations from the law of one price are not much larger in

\footnotetext{
${ }^{22} \mathrm{An}$ alternative is that such a relationship is working through cross-country differences in factor endowments, as in Kravis and Lipsey (1983).
} 
the euro area than they are in the United States. To the extent that the United States is a relevant benchmark, these results suggest that the scope for further price convergence among current members of the euro area may be limited. At the same time, deviations from the law of one price in both regions are large, implying some room for additional convergence going forward.

Finally, I find that price convergence has robustly contributed to observed inflation differences in the euro area, but that its importance varies from country to country and other forces explain more of the cross-country differences in inflation.

\section{References}

Balassa, Bela (1964). "The Purchasing Power Parity Doctrine: A Re-Appraisal," Journal of Political Economy, 72: 584-596.

Canzoneri, Matthew, Robert Cumby, Behzad Diba, and Gwen Eudey (2000). "Productivity Trends in Europe: Implications for Real Exchange Rates, Real Interest Rates, and Inflation," mimeo, Georgetown University.

Cecchetti, Steven G., Nelson C. Mark, and Robert J. Sonora (2000). "Price Level Convergence Among United States Cities: Lessons for the European Central Bank," NBER w.p. 7681.

Crucini, Mario J., Chris I. Telmer, and Marios Zachariadis (2000) "Dispersion in Real Exchange Rates," mimeo, Vanderbilt University.

DeGregorio, Jose, Alberto Giovannini, and Holger Wolf (1994). "International Evidence on Tradeables and Non-Tradeables Inflation," European Economic Review, 38: 1225-1244. Economist Intelligence Unit (1998) "Worldwide Cost of Living Survey," mimeo, London. 
Engel, Charles, and John H. Rogers (1996). "How Wide is the Border?" American Economic Review, 86: 1112-1125.

Hufbauer, Gary, Wada, Erika., and Warren Tony (2000). "The Benefits of Price Convergence," mimeo, Institute for International Economics, Washington, D.C.

Kravis, Irving B., and Robert E. Lipsey (1983). Toward an Explanation of National Price Levels. Princeton Studies in International Finance, 52.

Gust, Christopher, and Jaime Marquez (2000). "Productivity Developments Abroad," Federal Reserve Bulletin (October), 665-681, www.federalreserve.gov/pubs/bulletin.

Obstfeld, Maurice, and Kenneth Rogoff (1996). Foundations of International Macroeconomics, Cambridge: The MIT Press.

Rogers, John H. (2000). "Price Level Convergence and Inflation in Europe," mimeo, Board of Governors of the Federal Reserve System, Washington, D.C.

Rogers, John H., Gary Hufbauer, and Erika Wada (2001). "Price Level Convergence and Inflation in Europe," working paper 01-1, Institute for International Economics, Washington, D.C.

Romer, David (1993). "Openness and Inflation," Quarterly Journal of Economics, 108: 869-904. Samuelson, Paul. (1964). "Theoretical Notes on Trade Problems," Review of Economics and Statistics, 64: 145-154.

Summers, Robert, and Alan Heston (1991). The Penn World Table (Mark 5): An Expanded Set of International Comparisons, 1950-88," Quarterly Journal of Economics, 106: 327-368. 


\section{Table 1A: How Much Have Prices in the Euro Area Converged?}

Standard deviation of prices across locations

\begin{tabular}{lllll} 
& Price Index & 1990 & 1995 & 1999 \\
\hline Euro Area & Overall & 0.12 & 0.12 & 0.11 \\
& Tradeables & 0.12 & 0.08 & 0.06 \\
& Non-tradeables & 0.27 & 0.33 & 0.31 \\
\multirow{2}{*}{ United States } & & & \\
& Overall & 0.16 & 0.15 & 0.17 \\
& Tradeables & 0.05 & 0.04 & 0.04 \\
& Non-tradeables & 0.51 & 0.52 & 0.57 \\
\hline
\end{tabular}

Maximum-minimum spread across locations

\begin{tabular}{lllll} 
& Price Index & 1990 & 1995 & 1999 \\
\hline Euro Area & Overall & 0.60 & 0.45 & 0.41 \\
& Tradeables & 0.58 & 0.30 & 0.25 \\
& Non-tradeables & 1.02 & 1.14 & 1.07 \\
United States & & & \\
& Overall & 0.64 & 0.57 & 0.58 \\
& Tradeables & 0.18 & 0.14 & 0.14 \\
& Non-tradeables & 1.86 & 1.83 & 1.93 \\
\hline
\end{tabular}

Note: results for the sample using the $75 \%$ cut-off rule for including series. 


\section{Table 1B: How Much Have Prices in the Euro Area Converged?}

(Robustness check)

Standard deviation of prices across locations

\begin{tabular}{lllll} 
& Price Index & 1990 & 1995 & 1999 \\
\hline Euro Area & Overall & 0.15 & 0.12 & 0.11 \\
& Tradeables & 0.12 & 0.08 & 0.06 \\
& Non-tradeables & 0.63 & 0.60 & 0.59 \\
United States & & & \\
& Overall & 0.19 & 0.19 & 0.25 \\
& Tradeables & 0.04 & 0.03 & 0.03 \\
& Non-tradeables & 1.20 & 1.20 & 1.59 \\
\hline
\end{tabular}

Maximum-minimum spread across locations

\begin{tabular}{lllll} 
& Price Index & 1990 & 1995 & 1999 \\
\hline Euro Area & Overall & 0.69 & 0.49 & 0.46 \\
& Tradeables & 0.59 & 0.29 & 0.23 \\
& Non-tradeables & 2.01 & 2.35 & 2.34 \\
United States & & & \\
& Overall & 0.78 & 0.70 & 0.89 \\
& Tradeables & 0.12 & 0.11 & 0.12 \\
& Non-tradeables & 4.81 & 4.35 & 5.98 \\
\hline
\end{tabular}

Note: results for the sample using the "100\%" cut-off rule for including series. 


\section{Table 2: Explaining Inflation in Europe}

Dependent variable: 2000Q4 four-quarter HICP inflation

\begin{tabular}{|c|c|c|c|}
\hline & Euro Area & Europe & $\begin{array}{l}\text { Euro Area } \\
\text { (ex. energy) }\end{array}$ \\
\hline Constant & $\begin{array}{l}7.05 \\
(0.43)\end{array}$ & $\begin{array}{l}7.68 \\
(0.78)\end{array}$ & $\begin{array}{l}6.95 \\
(0.61)\end{array}$ \\
\hline 1999 price level & $\begin{array}{l}-4.53 \\
(0.30)\end{array}$ & $\begin{array}{l}-5.90 \\
(0.94)\end{array}$ & $\begin{array}{l}-3.14 \\
(0.70)\end{array}$ \\
\hline GDP growth, 1999 & $\begin{array}{l}0.24 \\
(0.02)\end{array}$ & $\begin{array}{l}0.12 \\
(0.08)\end{array}$ & $\begin{array}{l}0.39 \\
(0.04)\end{array}$ \\
\hline Output gap, 1999 & $\begin{array}{l}0.10 \\
(0.04)\end{array}$ & $\begin{array}{l}0.23 \\
(0.11)\end{array}$ & $\begin{array}{l}0.02 \\
(0.14)\end{array}$ \\
\hline 1999 relative per capita GDP $(\$)$ & $\begin{array}{l}-0.73 \\
(0.20)\end{array}$ & $\begin{array}{l}0.87 \\
(0.81)\end{array}$ & $\begin{array}{l}-4.19 \\
(0.26)\end{array}$ \\
\hline 1999 openness to non-EU trade & $\begin{array}{l}1.72 \\
(0.34)\end{array}$ & $\begin{array}{l}1.67 \\
(1.03)\end{array}$ & $\begin{array}{l}-0.29 \\
(0.51)\end{array}$ \\
\hline Adjusted $\mathrm{R}^{2}$ & 0.97 & 0.70 & 0.91 \\
\hline Variation explained by 1999 price level & $31 \%$ & $24 \%$ & $12 \%$ \\
\hline \# countries in sample & 11 & 17 & 11 \\
\hline
\end{tabular}

Note: heteroskedasticity-consistent standard errors are in parenthesis. Inflation variance explained by 1999 price level is the difference in the adjusted $\mathrm{R}^{2}$ from regressions with and without this variable included. Results are for the sample using the $75 \%$ cut-off rule for including series. 


\section{Table 3: The Importance of Price Level Convergence}

\begin{tabular}{lcc} 
Country & $\begin{array}{c}\text { Inflation deviation from } \\
\text { European average, 2000Q4 }\end{array}$ & Contribution of $\mathrm{P}^{1999}$ \\
\hline Netherlands & 0.2 & -0.4 \\
Greece & 1.1 & 1.2 \\
Spain & 1.3 & 0.8 \\
Germany & -0.3 & 0.1 \\
Belgium & 0.6 & 0.3 \\
Denmark & -0.2 & -0.8 \\
Ireland & 2.7 & 0.4 \\
Switzerland & -1.2 & -1.0 \\
Finland & 0.4 & -0.2 \\
Portugal & 0.9 & 1.1 \\
United Kingdom & -1.8 & -1.2 \\
Luxembourg & 1.6 & 0.8 \\
France & -0.7 & -1.0 \\
Italy & 0.04 & 0.7 \\
Norway & 0.2 & -0.8 \\
Sweden & -1.3 & 0.7 \\
Austria & E. & 0.7 \\
\hline
\end{tabular}

Note: calculations use the estimates in specification (2) of Table 2. 


\section{Table 4: Robustness Analysis of Inflation Regressions}

Dependent variable: 2000Q4 four-quarter HICP inflation

\begin{tabular}{|c|c|c|c|c|}
\hline & $\begin{array}{c}\text { Weighted } \\
\text { least squares }\end{array}$ & $\begin{array}{l}100 \% \text { cut- } \\
\text { off rule }\end{array}$ & Productivity & $\begin{array}{l}\text { Tradeables vs. } \\
\text { non-tradeables }\end{array}$ \\
\hline Constant & $\begin{array}{c}6.58 \\
(1.23)\end{array}$ & $\begin{array}{c}6.46 \\
(0.64)\end{array}$ & $\begin{array}{c}7.37 \\
(0.54)\end{array}$ & $\begin{array}{c}6.68 \\
(0.42)\end{array}$ \\
\hline Overall price level, 1999 & $\begin{array}{l}-4.23 \\
(1.54)\end{array}$ & $\begin{array}{l}-3.82 \\
(0.55)\end{array}$ & $\begin{array}{l}-7.50 \\
(0.89)\end{array}$ & ---- \\
\hline GDP growth, 1999 & $\begin{array}{c}0.27 \\
(0.02)\end{array}$ & $\begin{array}{c}0.36 \\
(0.06)\end{array}$ & $\begin{array}{c}0.17 \\
(0.05)\end{array}$ & $\begin{array}{c}0.23 \\
(0.01)\end{array}$ \\
\hline Output gap, 1999 & $\begin{array}{l}-0.01 \\
(0.54)\end{array}$ & $\begin{array}{c}0.03 \\
(0.08)\end{array}$ & $\begin{array}{c}0.26 \\
(0.07)\end{array}$ & $\begin{array}{c}0.11 \\
(0.03)\end{array}$ \\
\hline Relative per capita GDP, 1999 & $\begin{array}{l}-0.68 \\
(0.63)\end{array}$ & $\begin{array}{l}-1.12 \\
(0.41)\end{array}$ & $\begin{array}{c}3.91 \\
(0.86)\end{array}$ & $\begin{array}{l}-0.86 \\
(0.17)\end{array}$ \\
\hline Openness to non-EU trade, 1999 & $\begin{array}{c}1.76 \\
(1.27)\end{array}$ & $\begin{array}{c}0.41 \\
(0.79)\end{array}$ & ---- & $\begin{array}{c}1.48 \\
(0.28)\end{array}$ \\
\hline Traded goods price level, 1999 & ---- & ---- & ---- & $\begin{array}{l}-2.03 \\
(0.31)\end{array}$ \\
\hline Non-tradeables price level, 1999 & ---- & ---- & ---- & $\begin{array}{l}-1.40 \\
(0.09)\end{array}$ \\
\hline Labor productivity growth, 1999 & ---- & ---- & $\begin{array}{c}0.06 \\
(0.07)\end{array}$ & ---- \\
\hline Adjusted $\mathrm{R}^{2}$ & 0.99 & 0.90 & 0.73 & 0.98 \\
\hline \# countries in sample & 11 & 11 & 10 & 11 \\
\hline
\end{tabular}

Note: heteroskedasticity-consistent standard errors are in parenthesis. In specifications:

(1) residuals are weighted by 1999 population; (2) the 1999 price level is computed using the sample determined by the $100 \%$ cut-off rule for including series, instead of the $75 \%$ cut-off rule; (3) adds the 1999 growth rate of labor productivity in manufacturing to specification 1 of Table 2 (there is no productivity data for Luxembourg); (4) the 1999 overall price is replaced by the 1999 price levels for tradeables and non-tradeables (the $75 \%$ cut-off rule is used). 


\section{Table 5: Implications for Potential Future Euro Area Members}

Price indexes for three East European cities

(European average overall price index $=1.0$ each year)

\begin{tabular}{lllll} 
& Price Index & 1990 & 1995 & 1999 \\
\hline Budapest & Overall & 0.39 & 0.46 & 0.58 \\
& Tradeables & 0.35 & 0.36 & 0.43 \\
& Non-tradeables & 0.48 & 0.73 & 0.99 \\
Warsaw & Overall & 0.30 & & \\
& Tradeables & 0.25 & 0.74 & 0.66 \\
& Non-tradeables & 0.40 & 0.52 & 0.53 \\
& & & 1.36 & 1.02 \\
Prague & Overall & 0.36 & 0.59 & 0.65 \\
& Tradeables & 0.32 & 0.53 & 0.55 \\
& Non-tradeables & 0.48 & 0.75 & 0.94 \\
\hline
\end{tabular}

Note: indexes are normalized as above, so that the Euro Area average equals 1.0 for the overall price index each year. HICP weights for Greece are used to construct the indexes. 


\section{Appendix}

\section{A. Construction of the Price Indexes}

The objective is to take the raw price data from the EIU sample of goods and services, listed in Table A-1, and construct an index as close as possible conceptually to the national consumer price index. I first divided the price of each of the 153 items in each of the 26 cities by the average price of that particular item across all cities. Then I weight the "de-meaned" prices to construct the price index for location $\mathrm{k}, p_{k}{ }^{w}$, as:

$$
p_{k}^{w}=\sum_{i=1}^{153} \alpha_{i k}\left(\frac{p_{i k}}{\frac{1}{26} \sum_{k=1}^{26} p_{i k}}\right)
$$

where the items are weighted equally within categories of the European Harmonized Index of Consumer Prices, using the country-specific weights listed in Table A-2.

\section{B. Data Sources}

HICP inflation rates and GDP growth rates were taken from the Eurostat database. Per capita GDP relative to the U.S. is calculated at PPP exchange rate by the IMF, and was obtained from the IMFs World Economic Outlook database, available at www.imf.org. The merchandise imports and exports used to construct our openness measures were obtained from the IMFs Direction of Trade Statistics database. The output gaps are from staff estimates in the International Finance Division of the Federal Reserve Board. 
Table A-1; List of Goods and Services

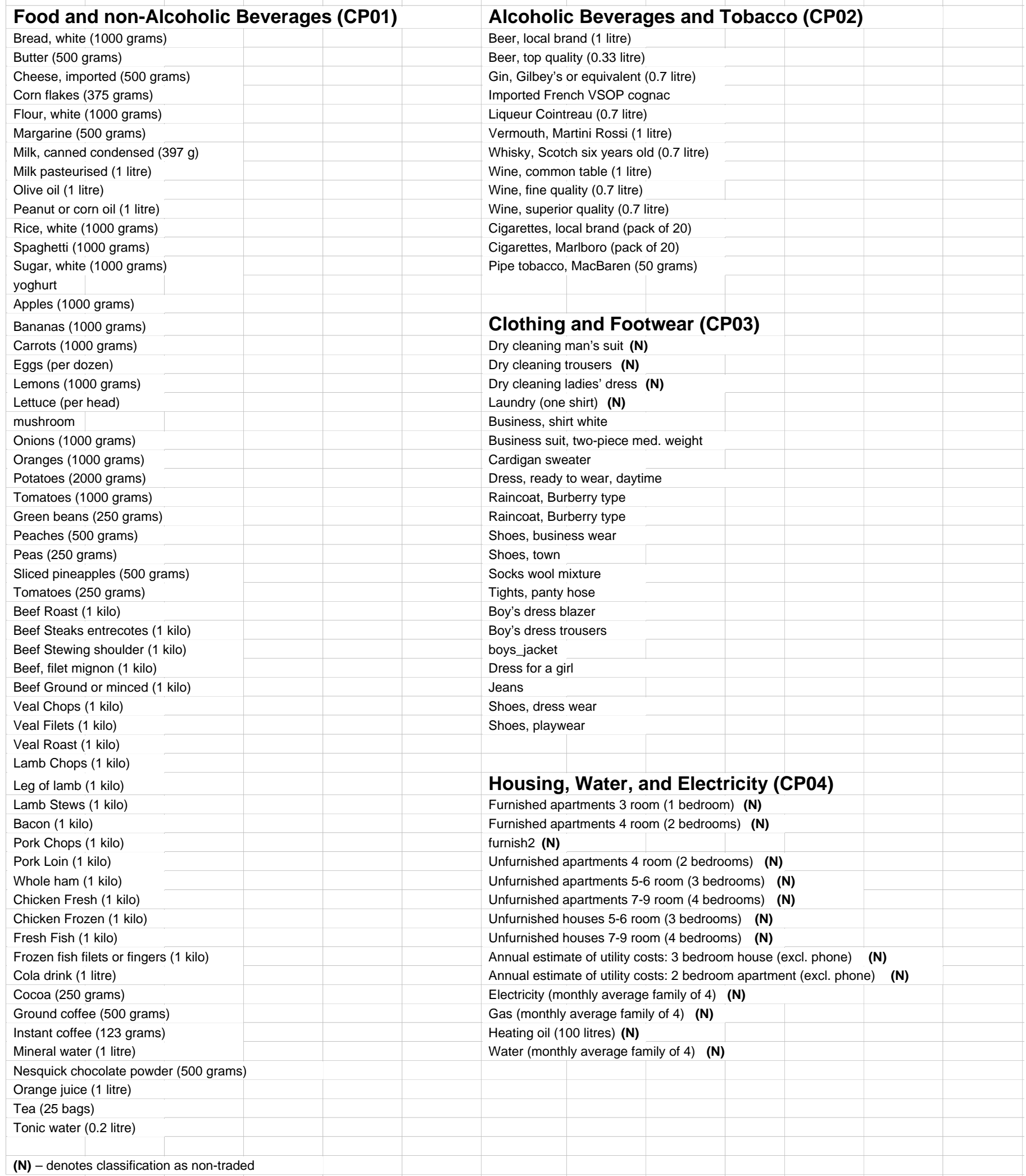




\section{Table A-1, cont'd}

\section{Furnishings and Household Equipment (CP05)}

Batteries (two for flashlight/radio use)

Electric toaster (two toasts)

Frying pan (Teflon or good equiv.)

Insect killer spray (330 grams)

Babysitter's rate per hour (N)

Hourly rate for dom. cleaning help (N)

Maid's monthly wages (N)

(fulltime living in, but excl. the cost of keep)

Laundry detergent (4.5 kilos)

Light bulbs (two 60 watts)

Liquid dishwashing deterg. (750 ml)

\section{Health (CP06)}

One x-ray at doctor's office or hospital (N)

Routine check-up at general or family doctor (N)

Visit to a dentist (one x-ray and one filling) (N)

\section{Transport (CP07)}

Compact car

Deluxe car

Family car

Low priced car

Annual premium for car insurance (N)

Cost of a tune-up (but no major repairs) (N)

High octane gasoline per litre

Regular_gasoline

Yearly road tax or registration fee (N)

Taxi Initial meter charge $\mathbf{( N )}$

Taxi Rate per additional kilometre (N)

Taxi ride from airport to city centre $(\mathbf{N})$

Weekly Car Rental Lowest Price all charges included (N)

Weekly Car Rental Moderate Price all charges included (N)

\section{Communications (CP08)}

Telephone, monthly rental (N)

Telephone, charge per local call from home (N)

\section{Recreation and Culture (CP09)}

Paperback novel (at bookstore)

Cinema 1 ticket (N)

Compact disc album

Four best seats at cinema (N)

Four best seats at a theatre or concert (N)

Purchase price of colour TV set $(56 \mathrm{~cm})$

Six tennis balls

Stereo record, one long-playing

Cost of developing 36 colour pictures (N)

Kodak colour film (C-1359 36 exposure)

Daily local newspaper

International foreign daily newspaper

International weekly newsmagazine (Time)

\section{Restaurants and Hotels (CP11)}

Fast food snack: hamburger and soft drink Three course dinner for four at a top restaurant (N)

Visit of four to a night-club (incl. one drink per person)

(N)

Two course meal for two persons (N)

One drink at bar of first class hotel (Scotch) (N)

Single room with bath one night at Hilton/Intercontinental type hot

Same as above for moderate but comfortable hotel (N)

Simple meal (N)

\section{Miscellaneous Goods and Services (CP12)}

\section{Soap, 1 bar bath size}

Toilet tissue (two rolls)

Aspirin (100 tablets)

Facial tissues (box of 100)

Hand lotion (125 ml)

Lipstick for women (deluxe type)

Lipstick for women (non-deluxe type)

Man's haircut (tips included) (N)

Razor blade (five pieces)

Shampoo

Toothpaste with fluoride (120 g)

Woman's haircut \& blow dry, with tips N) 


\section{Table A-2: Weights used to Construct the Price Indexes}

\begin{tabular}{|c|c|c|c|c|c|c|c|c|c|c|c|}
\hline & СР01 & $\mathrm{CP} 02$ & CP03 & CP04 & $\mathrm{CP} 05$ & СР06 & СР07 & CP08 & СР09 & CP11 & CP12 \\
\hline Belgium & 18.3 & 3.4 & 7.8 & 15.0 & 8.1 & 3.2 & 14.9 & 2.3 & 11.1 & 8.3 & 7.1 \\
\hline Denmark & 16.2 & 6.0 & 6.3 & 18.3 & 7.1 & 2.6 & 16.5 & 1.9 & 11.9 & 5.4 & 7.1 \\
\hline Germany & 14.0 & 4.8 & 7.5 & 20.8 & 7.7 & 3.4 & 15.4 & 2.1 & 11.5 & 5.1 & 7.0 \\
\hline Greece & 21.1 & 5.0 & 12.3 & 9.9 & 8.1 & 4.8 & 12.8 & 2.7 & 4.3 & 11.1 & 5.7 \\
\hline Spain & 24.4 & 3.4 & 10.7 & 10.5 & 5.9 & 2.3 & 13.7 & 1.4 & 6.5 & 15.2 & 4.6 \\
\hline France & 17.0 & 4.1 & 5.9 & 15.1 & 7.2 & 3.2 & 18.0 & 2.7 & 9.3 & 8.4 & 8.6 \\
\hline Ireland & 19.0 & 9.0 & 5.3 & 8.0 & 4.5 & 2.0 & 11.8 & 1.6 & 11.4 & 19.7 & 5.8 \\
\hline Italy & 17.4 & 2.9 & 11.1 & 10.1 & 11.0 & 3.4 & 15.0 & 2.8 & 7.4 & 10.2 & 7.6 \\
\hline Luxembourg & 12.0 & 10.1 & 7.6 & 11.0 & 10.8 & 1.4 & 19.2 & 1.3 & 11.0 & 9.6 & 5.9 \\
\hline Netherlands & 15.8 & 5.0 & 6.7 & 19.4 & 9.2 & 2.2 & 13.5 & 2.0 & 12.1 & 7.2 & 5.3 \\
\hline Austria & 13.1 & 4.0 & 8.3 & 13.9 & 9.0 & 1.9 & 14.5 & 3.2 & 11.6 & 14.3 & 5.4 \\
\hline Portugal & 21.6 & 3.3 & 7.0 & 9.3 & 7.9 & 5.7 & 20.5 & 2.1 & 3.9 & 13.1 & 3.9 \\
\hline Finland & 17.3 & 7.3 & 5.4 & 15.8 & 5.1 & 4.5 & 16.3 & 2.4 & 11.5 & 9.4 & 4.7 \\
\hline Sweden & 15.7 & 5.3 & 7.3 & 19.5 & 5.8 & 3.0 & 15.8 & 3.6 & 11.4 & 6.4 & 6.0 \\
\hline U.K. & 12.1 & 5.7 & 7.0 & 11.8 & 7.8 & 1.4 & 16.1 & 2.5 & 14.9 & 13.7 & 5.7 \\
\hline Norway & 14.1 & 3.0 & 6.9 & 16.4 & 7.5 & 2.7 & 22.3 & 2.1 & 13.6 & 4.5 & 5.6 \\
\hline
\end{tabular}

*See Table A-1 for a list of the categories. None of the items in our sample was assigned to category CP10, Education, whose weight is 0.9 percent in the euro area as a whole. 
Figure 1: Inflation Rates in the Euro Area

Euro Area Headline Inflation Rates*
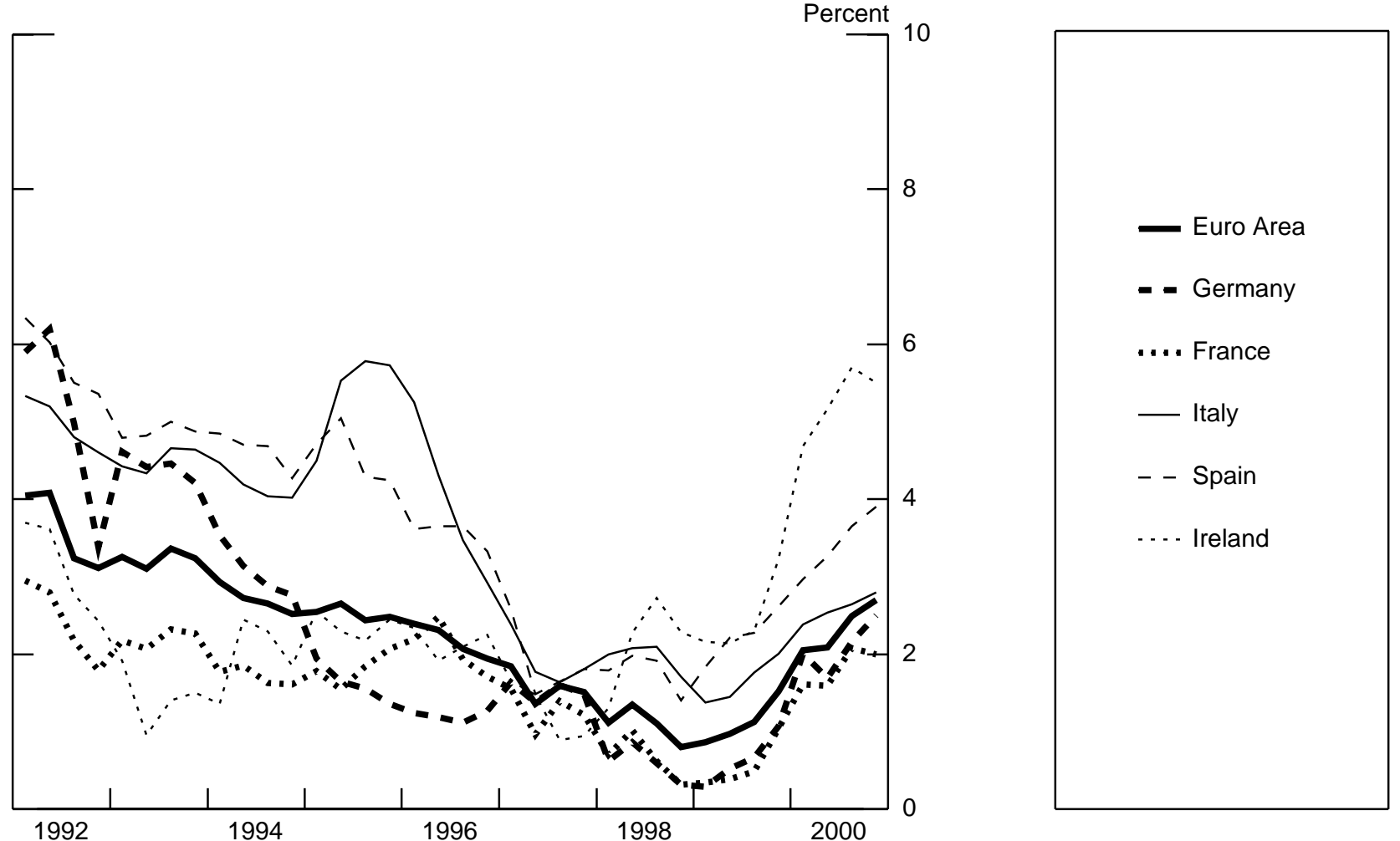

*4-quarter percent change in harmonized indexes of consumer prices (HICP); most recent observation is for 2000Q4. 
Figure 2: Price level convergence

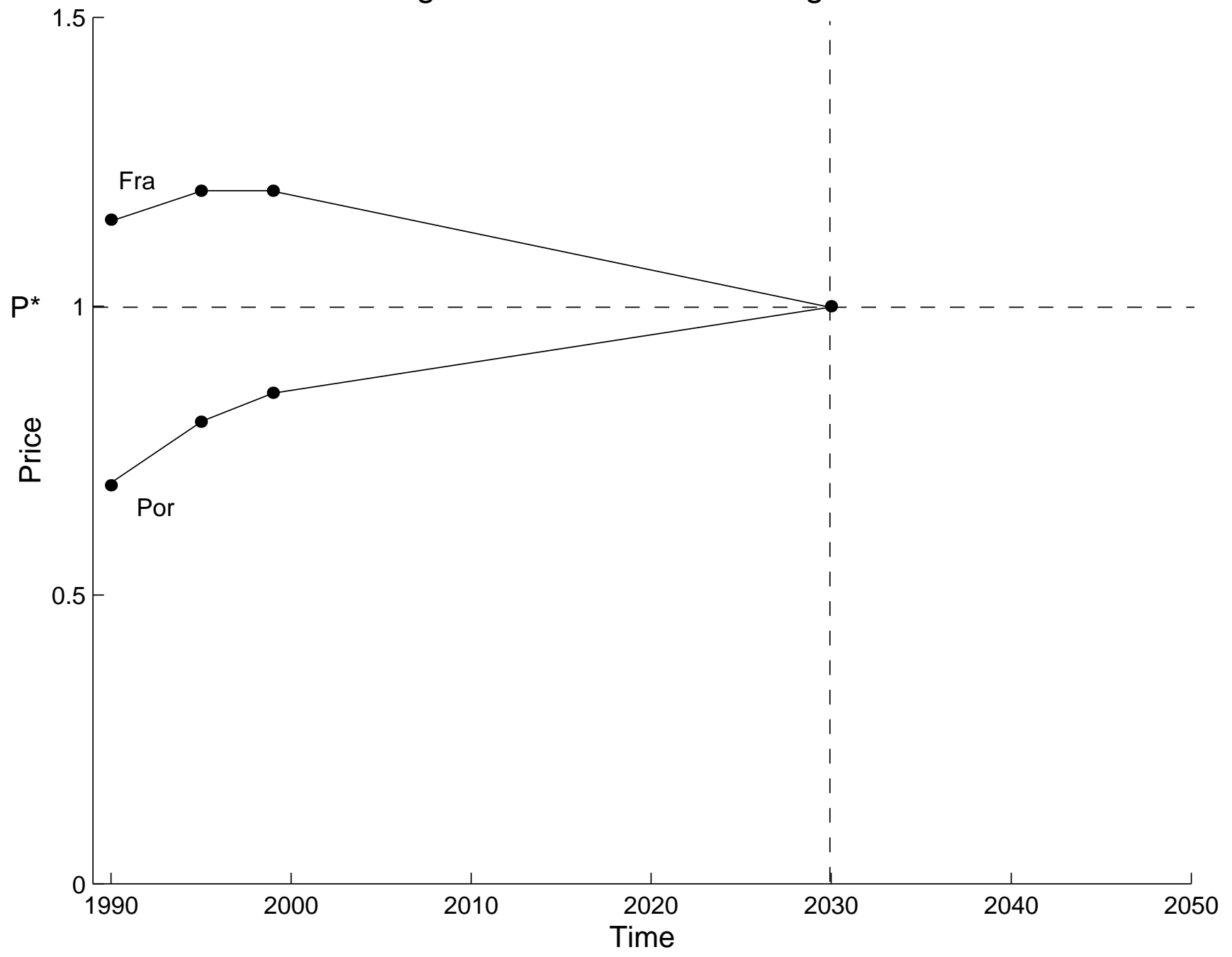


Figure 3: Price Levels and Per Capita GDP

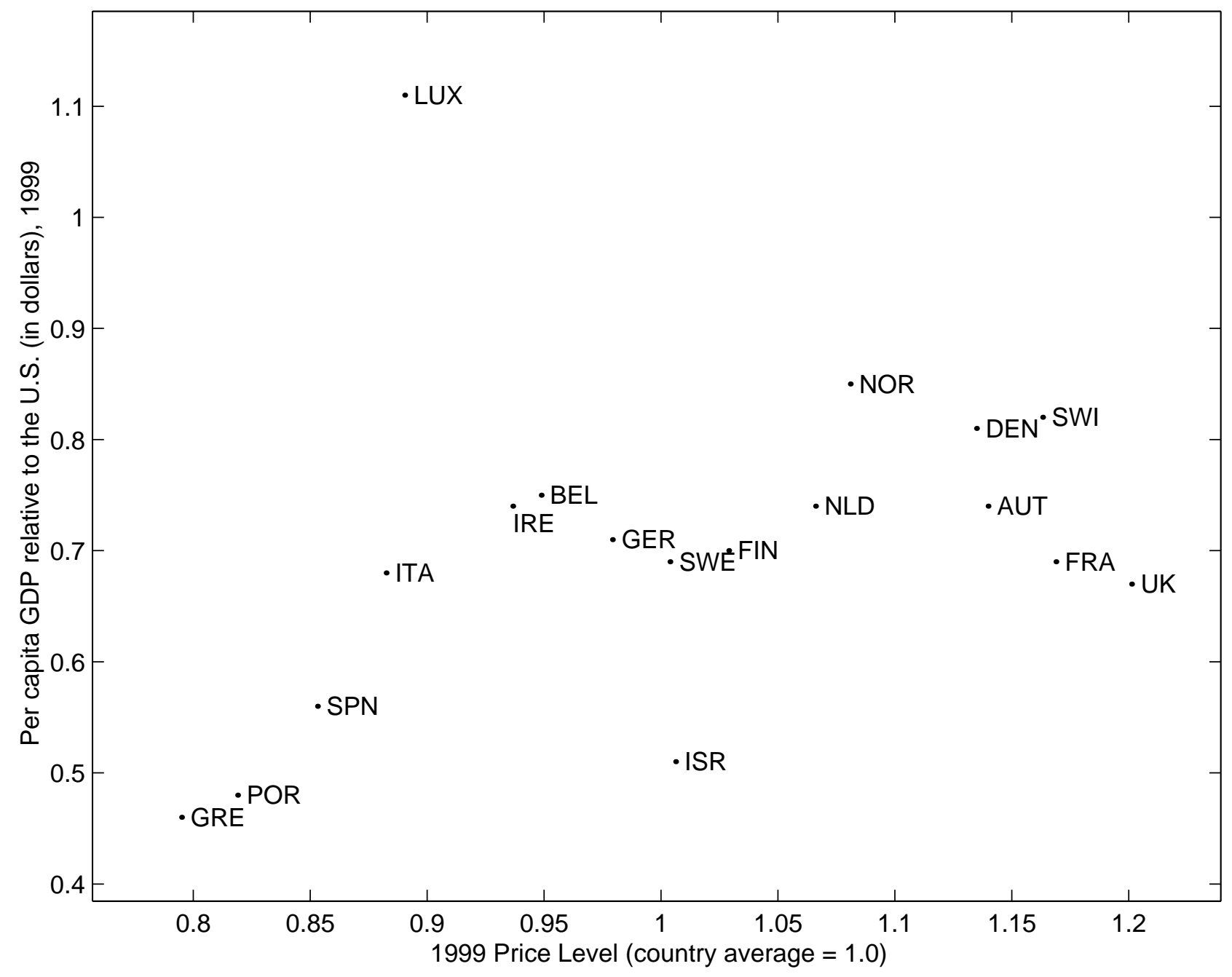


Figure 4: Relative Price of Non-tradeables and Labor Productivity

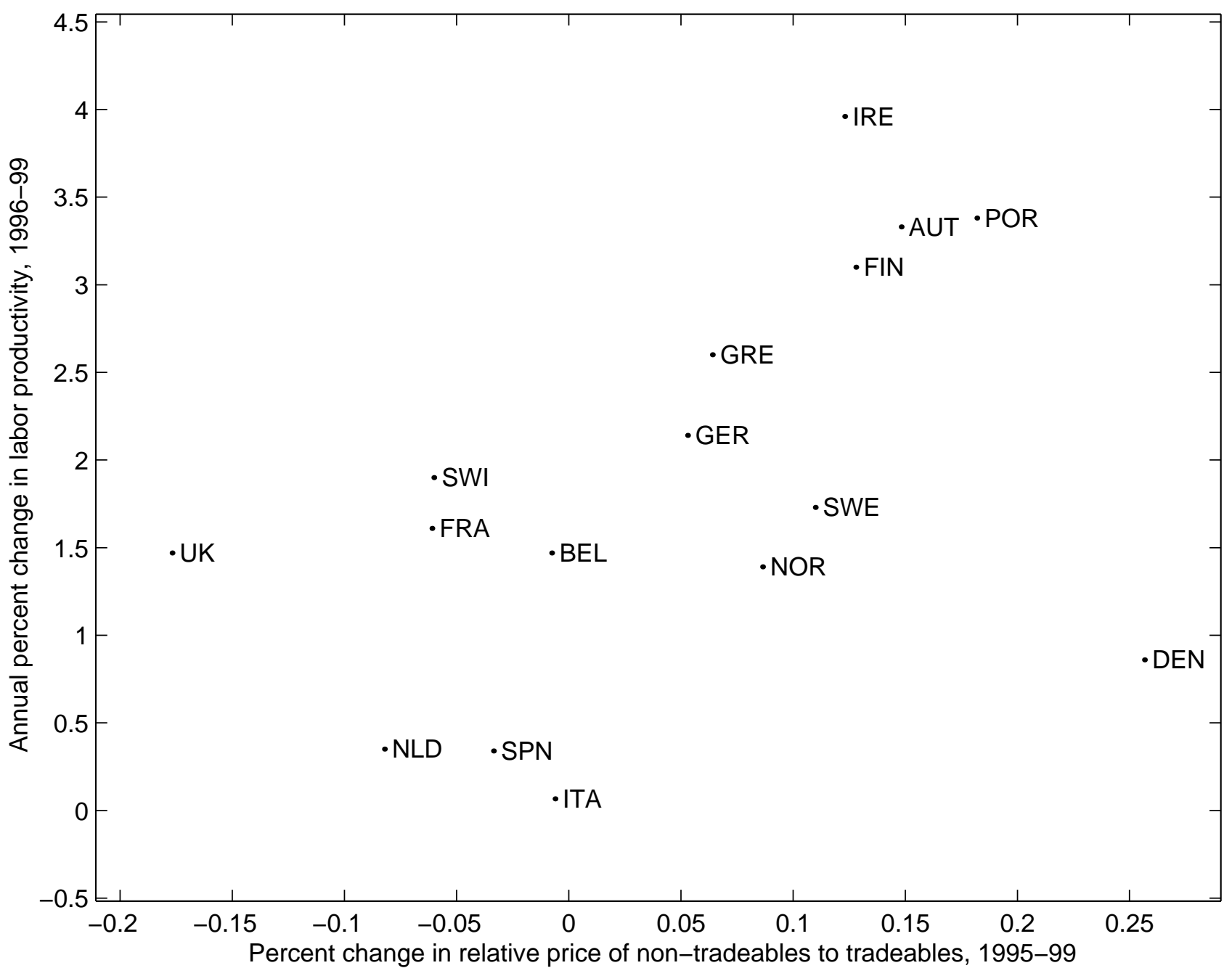


Figure 5: Deviations from the Law of One Price

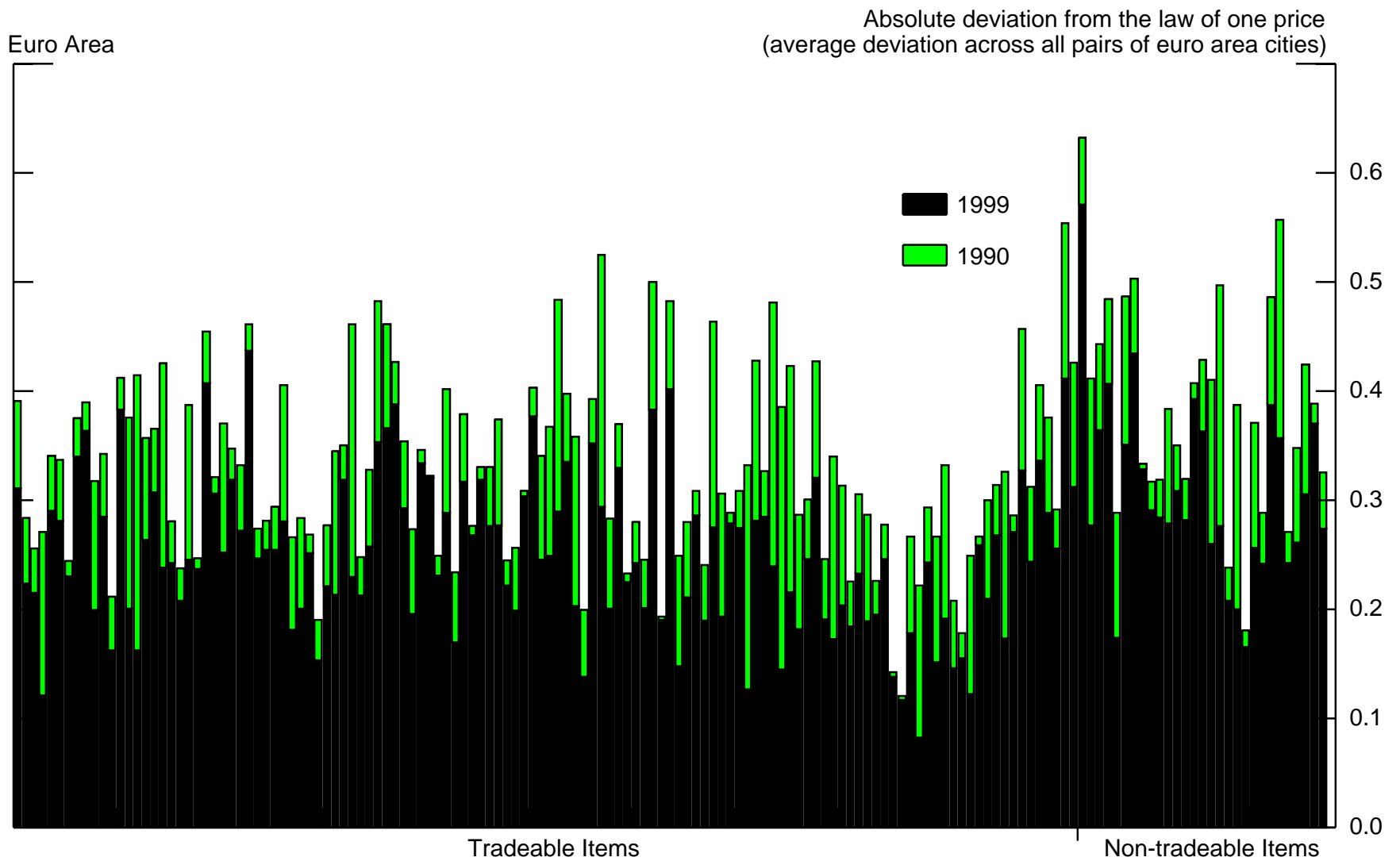

Euro Area less United States, 1999

Absolute deviation from the law of one price

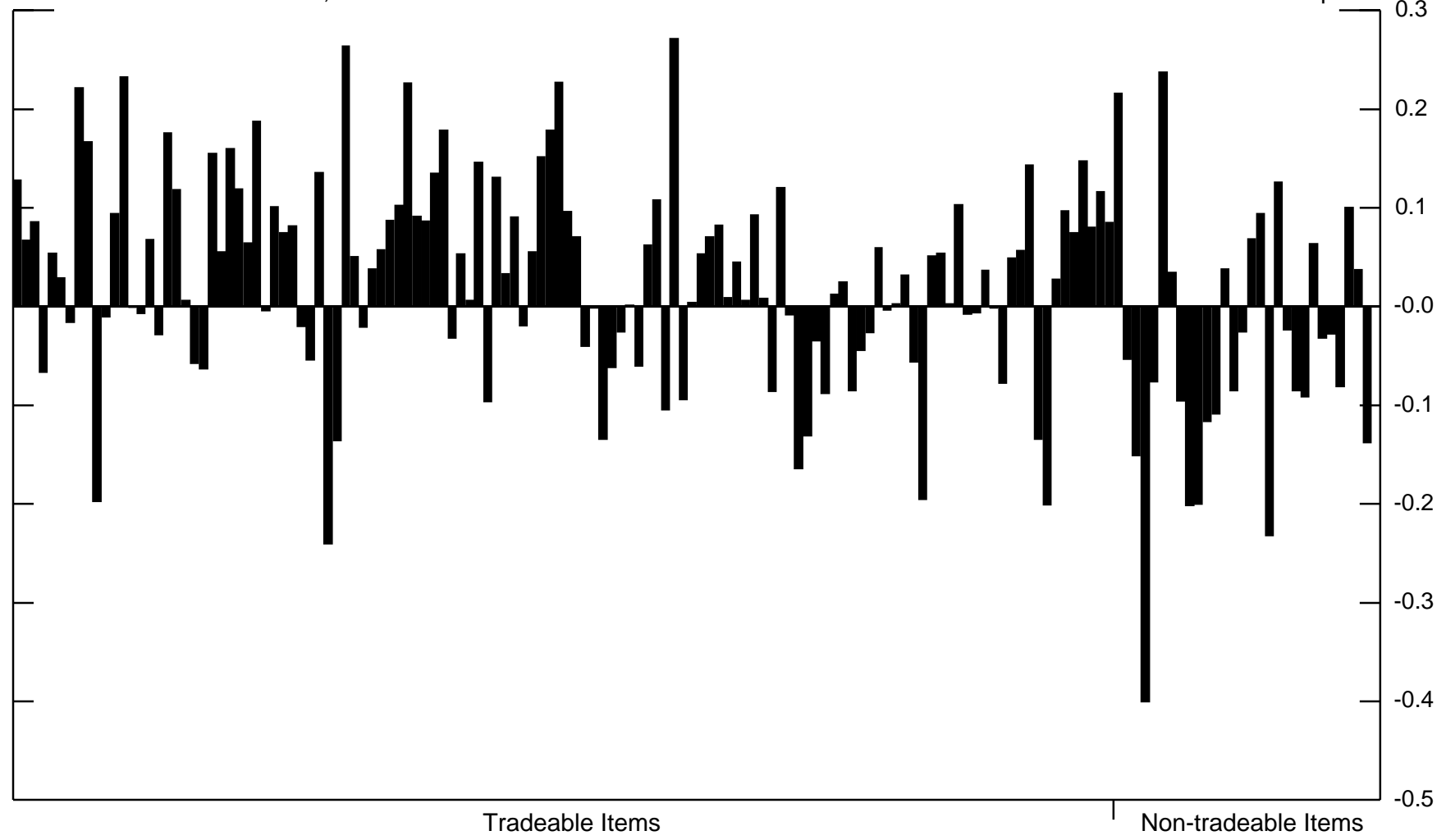


Figure 6: 2000 Inflation versus 1999 Price Level

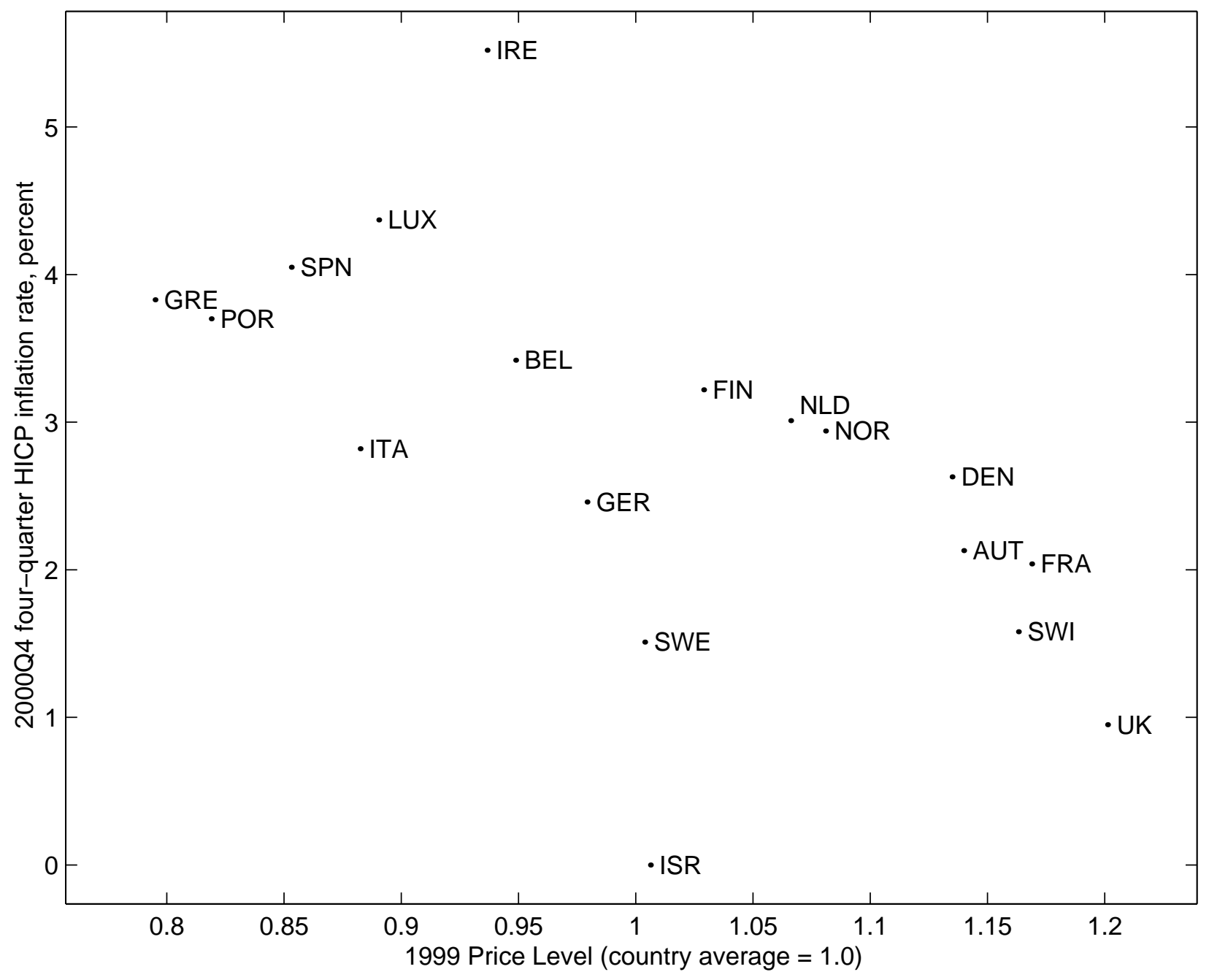

